\title{
The influence of smoking on the risk of Alzheimer's disease
}

\author{
C. Merchant, MD, MPH; M.-X. Tang, PhD; S. Albert, PhD, MSc; J. Manly, PhD; Y. Stern, PhD; \\ and R. Mayeux, MD, MSc
}

\begin{abstract}
Article abstract-Objective: To investigate the relationship between cigarette smoking and Alzheimer's disease (AD) in a prospective community-based study in northern Manhattan. Background: Results from previous case-control studies suggest that there is a protective effect of smoking on AD. However, the recent prospective Rotterdam Study found that there was an increased risk of $\mathrm{AD}$ for smokers, particularly those without an apolipoprotein $\mathrm{E}(A P O E)-\epsilon 4$ allele. Methods: The authors examined data from a community-based longitudinal study of local elders residing in northern Manhattan to determine whether tobacco use increases or decreases the risk of $\mathrm{AD}$. Information regarding the frequency of tobacco use was obtained in structured interviews at the baseline assessment. Standardized clinical assessments were subsequently completed on each subject at annual visits during which incident cases of $\mathrm{AD}$ were identified. Results: The relative risk (RR) of $\mathrm{AD}$ among former smokers was 0.7 (95\% CI, 0.5 to 1.1). The RR among current smokers was 1.9 (95\% CI, 1.2 to 3.0). Smokers without an $A P O E-\epsilon 4$ allele had the highest risk of $\mathrm{AD}(\mathrm{RR}=2.1 ; 95 \% \mathrm{CI}, 2.1$ to 3.7$)$ compared with those with an $A P O E-\epsilon 4$ allele $(\mathrm{RR}=1.4 ; 95 \% \mathrm{CI}, 0.6$ to 3.3). Conclusions: Our results are consistent with the observation that smoking increases the risk of $\mathrm{AD}$. However, we found that among previous smokers who quit smoking, there may be a slight reduction in the risk of $\mathrm{AD}$.
\end{abstract}

NEUROLOGY 1999;52:1408-1412

It has been proposed that smoking augments cholinergic metabolism by upregulation of cholinergic nicotinic receptors in the brain. ${ }^{1}$ Many of the manifestations of Alzheimer's disease $(\mathrm{AD})$ are attributed to alterations in acetylcholine metabolism ${ }^{2-4}$ and as a result, smoking was thought to decrease the risk or at least retard the onset of symptoms associated with $\mathrm{AD}$ through this mechanism.

Methodological limitations of previous case-control studies $^{5-7}$ have generated interest in conducting prospective studies to examine the relationship between smoking and $\mathrm{AD}$. A recent study from The Netherlands examined the association of cigarette smoking with dementia and AD. ${ }^{8}$ Their results show that in comparison with those who never smoked, smokers had a twofold increase risk of dementia and AD.

In our prospective community-based study, we examined data collected prospectively from elders residing in northern Manhattan. We postulated that the risk of $\mathrm{AD}$ would be elevated among current smokers compared with past smokers or those who do not have a smoking history. Recognizing the link between apolipoprotein $\mathrm{E}(A P O E)-\epsilon 4$ and $\mathrm{AD},,^{9-11}$ we posited that the $\epsilon 4$ allele might effect the association between smoking and $\mathrm{AD}$ risk.

Methods. Setting and participants. Data were analyzed from a sample of Medicare recipients in three contig- uous zip codes within the community of Washington Heights in northern Manhattan, New York City.

A total of 2,128 persons participated in the initial phase of the study. A 90-minute, in-person interview of general health and function was completed. This structured interview also included questions about years of formal education. The interview was followed by a standardized clinical assessment including a medical history, physical and neurologic examination, and a brief (approximately 1 hour) neuropsychological battery developed previously for use in this community. ${ }^{12,13}$ These same clinical assessments were used in the annual follow-up of all participants. The interviews were conducted in either English or Spanish. The Columbia University Institutional Review Board reviewed and approved this project. All participants provided written informed consent.

For this study data were excluded from 290 people $(13.6 \%)$ who were found demented at the initial interview (using the methods described), 349 (16.4\%) who refused subsequent follow-up, 155 (7\%) who died after the initial examination, $129(6.1 \%)$ missing smoking information, 25 (1.2\%) individuals with PD, 117 (5.5\%) with stroke, and 1 individual with both PD and stroke. All data from the remaining 1,062 elderly (730 women and 352 men) without dementia were considered appropriate for the investigation. Annual follow-up examinations were conducted over an average of 2.04 years.

$A D$ diagnosis. All participants were examined by a neurologist or an appropriately trained internist or psychi-

From the Gertrude H. Sergievsky Center (Drs. Merchant, Tang, Albert, Manly, Stern, and Mayeux), the Taub Center for Alzheimer's Disease Research in the City of New York (Drs. Merchant, Tang, Albert, Manly, Stern, and Mayeux), and the Departments of Neurology (Drs. Merchant, Stern, and Mayeux) and Psychiatry (Drs. Manly, Stern, and Mayeux), College of Physicians and Surgeons, Columbia University, New York, NY.

Supported by federal grants AG07232 and AG08702, the Charles S. Robertson Memorial Gift for Alzheimer's Disease from the Banbury Fund, and the Blanchette Hooke Rockefeller Fund.

Received October 20, 1998. Accepted in final form January 9, 1999.

Address correspondence and reprint requests to Dr. Richard Mayeux, G.H. Sergievsky Center, 630 West 168th Street, Columbia University, New York, NY 10032 . 
atrist, and all underwent neuropsychological testing. The data from the initial and follow-up examinations and interviews, and any existing medical records and imaging studies were reviewed collectively at a consensus conference of physicians and neuropsychologists to establish diagnoses. Clinicians were unaware of the $A P O E$ genotype during the diagnostic process. The diagnosis of dementia or the specific clinical diagnosis of $\mathrm{AD}$ was based on specified research criteria ${ }^{14,15}$ and required evidence of cognitive deficit on clinical evaluation in addition to objective neuropsychological findings, as well as evidence of impairment in social or occupational function. Patients meeting criteria $^{14}$ for probable or possible $\mathrm{AD}$ with a Clinical Dementia Rating ${ }^{16}$ score of 1.0 or higher were considered to have the clinical diagnosis of $\mathrm{AD}$. To exclude the diagnosis of mixed dementia (i.e., $\mathrm{AD}$ and vascular dementia), cerebrovascular disease was identified by a clinical history of stroke or TIA, or by evidence of cerebrovascular lesions on brain imaging. All those with any history of cerebrovascular disease or mixed dementia were excluded from the study.

Ethnic group. For ethnic group classification we used the format suggested by the 1990 United States Census Bureau. ${ }^{17}$ In the first question, participants were asked to which ethnic group they belonged. The possible responses included white, black (African American or Caribbean American), American Indian, Asian, or other. Regardless of the response, a second question asked whether or not the person being interviewed considered him or herself Hispanic. Several choices were then provided to indicate specific Hispanic origin (e.g., Puerto Rico, Dominican Republic, Cuba). Each individual was also asked to identify the country of their birthplace. For this study, we used the categories of black (non-Hispanic), white (non-Hispanic), and Hispanic consistent with the census data.

Risk factor interview. A structured risk factor questionnaire was developed for the assessment of exposures to putative risk factors related to dementia. ${ }^{18}$ The interviews were given in English and Spanish according to the preference of the patient.

For smoking there were three sets of questions. A trigger question asked whether or not the individual ever smoked at least one cigarette per day for a period of 1 year or more. If the answer was no, no further questions were asked. If the subject answered yes, the individual was asked at what age they began smoking, whether they were still smoking, at what age they had stopped if no longer smoking, and how many cigarettes on average they had smoked or still smoked per day.

The two other sets of smoking questions asked about cigar and pipe use. Both began with a trigger question asking whether the individual had ever smoked a cigar or pipe. If the subject answered no, no further questions were asked. If the subject answered yes, follow-up questions similar to those for cigarettes were asked but referred to the number of cigars or pipe-fulls smoked daily.

A composite vascular "heart" disease variable was formulated to assess whether cardiac disease may act as a possible confounder of $\mathrm{AD}$. The vascular disease variable included anyone reporting a history of myocardial infarction, congestive heart failure, angina, and anyone taking cardiac medication.

$A P O E$ genotyping. The $A P O E$ genotype for each participant was determined after isolating DNA from white
Table 1 Demographic profile of population-based study

\begin{tabular}{lcc}
\hline Characteristics & Alzheimer's disease & Total at risk \\
\hline $\mathrm{n}$ & 142 & 920 \\
Women, n (\%) & $99(69.7)$ & $631(68.6)$ \\
Age, y (SD) & $77.2(5.7)^{*}$ & $75.1(6.2)$ \\
Education, y (SD) & $7.1(3.8)^{*}$ & $9.0(4.5)$ \\
Ethnic group, n (\%) & & \\
$\quad$ African American & $57(40.1)$ & $291(31.6)$ \\
$\quad$ White & $21(14.8)$ & $238(25.9)$ \\
$\quad$ Hispanic & $62(43.7)$ & $386(42.0)$ \\
Smoking status, n (\%) & & \\
$\quad$ Never & $79(55.6)$ & $451(49.0)$ \\
Past & $36(25.4)$ & $325(35.3)$ \\
Current & $27(19.0)$ & $144(15.7)$ \\
\hline
\end{tabular}

* Indicates significant difference from the total at-risk group based on chi-square analysis.

blood cells and digesting the DNA with HhaI ${ }^{19}$ Leukocyte DNA was amplified by PCR using specifically synthesized oligonucleotide primers and Taq polymerase modified from those described by Hixson and others. ${ }^{20,21}$ The digested PCR fragments were then separated by electrophoresis.

Data analysis. The frequencies for each demographic variable (age, gender, education, and ethnic group) and for smoking were compared among those at-risk participants and those with $\mathrm{AD}$ using chi-square analyses and Fisher's exact tests. ${ }^{22}$

Risk ratio estimates were calculated to assess the relationship between $\mathrm{AD}$ and smoking, in addition to other demographic variables. Univariate measures of association were estimated from chi-square analysis. Multivariate risk ratios were estimated from Cox proportional hazard models for each risk factor. ${ }^{23}$ As recommended by Korn et al., ${ }^{23}$ the time-to-event variable was the age at onset of $\mathrm{AD}$; therefore, no further age adjustment was required. The first stage of assessment included only smoking history. We then included education, and the final model included education in addition to ethnicity, and $A P O E$ genotype. This information was used to identify differences with respect to education and ethnic group identity represented in the community.

Results. Demographics. Table 1 shows the demographic characteristics of the study participants by $\mathrm{AD}$ and nondemented control subjects. Obvious group differences were apparent for age at interview and education. Patients with $\mathrm{AD}$ were significantly older than the control subjects $\left(\chi^{2}=25.0, p<0.001\right)$ and had the least amount of formal education $\left(\chi^{2}=26.4, p<0.001\right)$, whereas patients with $\mathrm{AD}$ were very similar to control subjects in ethnic group representation and smoking status.

Reliability. The test-retest reliability ${ }^{18}$ of the risk factor interview was in the good to excellent range for the questions regarding smoking $(\kappa=0.72)$.

Smoking. The frequency of smoking varied significantly by age and gender, but not by ethnic group or education (table 2). Smoking decreased with age, and varied by sex in that more women reported that they never 
Table 2 Smoking history by age, gender, education, and ethnic group

\begin{tabular}{|c|c|c|c|c|}
\hline \multirow[b]{2}{*}{ Characteristics } & \multirow[b]{2}{*}{$\mathrm{n}$} & \multicolumn{3}{|c|}{ Smokers, n (\%) } \\
\hline & & Current & Past & Never \\
\hline \multicolumn{5}{|l|}{ Age group, y } \\
\hline $65-74$ & 648 & $117(68.4)$ & $239(66.2)$ & $292(55.1)$ \\
\hline $75-84$ & 334 & $49(28.7)$ & $99(27.4)$ & $186(35.1)$ \\
\hline $85+$ & 80 & $5(2.9)^{*}$ & $23(6.4)$ & $52(9.8)$ \\
\hline \multicolumn{5}{|l|}{ Gender } \\
\hline Women & 730 & $89(52.0)$ & $204(56.5)$ & $437(82.5)$ \\
\hline Men & 332 & $82(48.0)$ & $157(43.5)$ & $93(17.5)^{*}$ \\
\hline \multicolumn{5}{|l|}{ Education, $\mathrm{y}^{\dagger}$} \\
\hline $0-7$ & 356 & $68(40.0)$ & $121(33.8)$ & $167(31.7)$ \\
\hline $8-11$ & 287 & $42(24.7)$ & $94(26.3)$ & $151(28.7)$ \\
\hline $12+$ & 412 & $60(35.3)$ & 143 (39.9) & $209(39.7)$ \\
\hline \multicolumn{5}{|l|}{ Ethnicity } \\
\hline African American & 348 & $74(44.3)$ & $117(32.4)$ & $157(29.8)$ \\
\hline White & 259 & $35(21.0)$ & $92(25.5)$ & $132(25.0)$ \\
\hline Hispanic & 448 & $58(34.7)$ & $152(42.1)$ & $238(45.2)$ \\
\hline
\end{tabular}

* Denotes a significant difference from the comparison groups in the same category based on chi-square analysis.

$\uparrow$ Owing to missing data on educational profile, seven participants were omitted.

$\ddagger$ There were seven participants who failed to classify themselves as either white, African American, or Hispanic.

smoked. There was no difference in tobacco use across ethnic groups. The majority of smokers were cigarette smokers. Only four patients with $\mathrm{AD}$ and five nondemented subjects restricted their smoking to cigars or a pipe. A few in each group smoked cigars or a pipe as well as cigarettes according to our definition. We did not perform separate analyses for those who use only cigars or pipes because these were relatively infrequent as exposures. However, we did include cigar and pipe smokers in comparing smokers with nonsmokers. Among those who quit smoking, the mean time since cessation was 21.4 years. Because it was possible that smoking might have delayed or hastened the onset of $\mathrm{AD}$, we compared the age at onset of symptoms between smokers and nonsmokers with $\mathrm{AD}$. The mean age at onset of symptoms for smokers with $\mathrm{AD}$ was significantly lower than for nonsmokers (nonsmokers, $80.9 \pm 5.9$ versus smokers, $76.5 \pm 4.9$; $p<0.001$ ).

Alzheimer's disease. Although there were no statistically significant differences in the risk of developing $\mathrm{AD}$ between current smokers, past smokers, and those who reported never smoking on univariate analysis $\left(\chi^{2}=5.5\right.$, $p<0.06$ ), there were slightly more current smokers among the subjects (see table 1). Multivariate analysis showed that a past history of smoking was not associated significantly with $\mathrm{AD}$ (relative risk $[\mathrm{RR}]=0.7 ; 95 \% \mathrm{CI}, 0.5$ to 1.1). However, those who were current smokers had an increased risk of developing $\mathrm{AD}$ as indicated by the unadjusted $\mathrm{RRs}$ and $\mathrm{CIs}$ in table $3(\mathrm{RR}=1.9 ; 95 \% \mathrm{CI}, 1.2$ to 3.0). Adjustment for education and ethnicity did not alter the measure of association between smoking and $\mathrm{AD}$
Table 3 Relative risk estimates for smoking in $A D$

\begin{tabular}{lcccc}
\hline & & & \multicolumn{2}{c}{$\begin{array}{c}\text { Relative risk estimates } \\
\text { [95\% CI] }\end{array}$} \\
\cline { 4 - 5 } Tobacco use & $\begin{array}{c}\text { Total at } \\
\text { risk, } \mathrm{n}\end{array}$ & $\mathrm{AD}, \mathrm{n}(\%)$ & Crude & Adjusted \\
\cline { 3 - 5 } Never & 672 & $79(11.8)$ & 1.0 reference & 1.0 reference \\
Past & 361 & $36(9.9)$ & $0.8[0.5-1.1]$ & $0.7[0.5-1.1]$ \\
Current & 171 & $27(15.8)$ & $1.9[1.2-3.0]$ & $1.7[1.1-2.8]$ \\
\hline
\end{tabular}

* Multivariate analysis adjusted for education and ethnicity.

$(\mathrm{RR}=1.7 ; 95 \% \mathrm{CI}, 1.1$ to 2.8$)$. The association between smoking and $\mathrm{AD}$ was slightly lowered in the presence of $A P O E-\epsilon 4(\mathrm{RR}=1.4 ; 95 \% \mathrm{CI}, 0.6$ to 3.3 ; table 4$)$, but not for current smokers without $A P O E-\epsilon 4(\mathrm{RR}=2.1 ; 95 \% \mathrm{CI}, 1.2$ to 3.7). Table 5 lists the distribution of smoking history by $\mathrm{AD}$ status, $A P O E$ status, and age group.

After reviewing these results additional questions arose concerning vascular disease acting as a possible confounder. Smoking is a risk factor for vascular disease. Cardiac disease increases the risk of vascular dementia. Therefore, we looked at two additional multivariate models (multiplicative and additive) to determine the likelihood of interaction. The multiplicative proportional hazard model included ethnic group, smoking history, and a composite vascular "heart" disease variable. In the multiplicative model there was no evidence of interaction among those who were both current smokers and had cardiac disease (current smokers: $\mathrm{RR}=1.9 ; 95 \% \mathrm{CI}, 1.1$ to 3.3 ; heart disease: $\mathrm{RR}=1.1 ; 95 \% \mathrm{CI}, 0.72$ to 1.78 ; current smokers $\times$ heart disease: $\mathrm{RR}=1.1 ; 95 \% \mathrm{CI}, 0.4$ to 3.2 ). In the additive model, which included all of the variables just listed, there was the suggestion of interaction among those who were both current smokers and had cardiac disease (current smokers: $\mathrm{RR}=1.9 ; 95 \% \mathrm{CI}, 1.1$ to 3.3 ; heart disease: $\mathrm{RR}=$ 1.1; $95 \%$ CI, 0.7 to 1.8; current smokers and heart disease: $\mathrm{RR}=2.4 ; 95 \% \mathrm{CI}, 0.97$ to 5.7 ). However, the number of individuals in this group was small $(\mathrm{n}=14)$, thus limiting the interpretation. Finally, stratification by heart disease did not alter the relationship between smoking and $\mathrm{AD}$ in those with and without $A P O E-\epsilon 4$.

Table 4 Relative risk estimates forAPOE- $\epsilon 4$ status

\begin{tabular}{lccc}
\hline & & & Relative risk \\
Risk & Total at & $\mathrm{AD}, \mathrm{n}$ & estimates \\
factors & risk, $\mathrm{n}$ & $(\%)$ & {$[95 \% \mathrm{CI}]$}
\end{tabular}

Tobacco use in $A P O E-\epsilon 4$ carriers

\begin{tabular}{lrrl} 
Never & 118 & $24(20.3)$ & 1.0 reference* \\
Past & 103 & $14(13.6)$ & $0.8[0.4-1.5]$ \\
$\quad \begin{array}{c}\text { Current } \\
\text { Tobacco use in } \\
\text { non-APOE- }-4 \\
\quad \text { carriers }\end{array}$ & 41 & $7(17.1)$ & $1.4[0.6-3.3]$ \\
Never & & & \\
Past & 336 & $52(15.5)$ & 1.0 reference* \\
Current & 210 & $18(8.6)$ & $0.6[0.3-1.1]$ \\
\hline
\end{tabular}

* Multivariate analysis adjusted for education and ethnicity. 
Table 5 Smoking history by AD status, APOE status, and age group

\begin{tabular}{|c|c|c|c|c|}
\hline \multirow{2}{*}{$\begin{array}{l}\text { Age group and } \\
\text { smoking status }\end{array}$} & \multicolumn{2}{|c|}{$\begin{array}{c}\text { Non-APOE- } \epsilon 4 \text { carrier, } \\
\mathrm{n}(\%)\end{array}$} & \multicolumn{2}{|c|}{$\begin{array}{c}A P O E-\epsilon 4 \text { carrier } \\
\mathrm{n}(\%)\end{array}$} \\
\hline & $\mathrm{AD}+$ & $\mathrm{AD}-$ & $\mathrm{AD}+$ & $\mathrm{AD}-$ \\
\hline \multicolumn{5}{|l|}{$65-74$ y } \\
\hline Current & $8(36.4)$ & $49(16.8)$ & $1(7.7)$ & $22(16.8)$ \\
\hline Past & $5(22.7)$ & $104(35.6)$ & 3 (23.1) & $58(44.3)$ \\
\hline Never & $9(40.9)$ & $139(47.6)$ & $9(69.2)$ & $51(38.9)$ \\
\hline \multicolumn{5}{|l|}{$75-84$ y } \\
\hline Current & $8(20.5)$ & $23(12.0)$ & $3(15.0)$ & $8(14.0)$ \\
\hline Past & $5(12.8)$ & $68(35.6)$ & $6(30.0)$ & $19(33.3)$ \\
\hline Never & $26(66.7)$ & $100(52.4)$ & $11(55.0)$ & $30(52.6)$ \\
\hline \multicolumn{5}{|l|}{$85+y$} \\
\hline Current & $0(0)$ & $2(6.1)$ & $1(25.0)$ & $1(8.3)$ \\
\hline Past & $3(27.3)$ & 7 (21.2) & $1(25.0)$ & $6(50.0)$ \\
\hline Never & $8(72.7)$ & $24(72.7)$ & $2(50.0)$ & $5(41.7)$ \\
\hline
\end{tabular}

Discussion. The results of this prospective study demonstrate that current smokers had a slightly higher risk of $\mathrm{AD}$. The recent Rotterdam Study examined the effect of smoking on dementia and AD. ${ }^{8}$ Their results show that in comparison with those who never smoked, smokers had an increased risk of dementia ( $\mathrm{RR}=2.2 ; 95 \% \mathrm{CI}, 1.3$ to 3.6$)$ and $\mathrm{AD}(\mathrm{RR}=2.3 ; 95 \% \mathrm{CI}, 1.3$ to 4.1$)$. Our results are consistent with the Rotterdam Study findings in this respect. Complementary results were also found with respect to the effect modification role of $A P O E$ $\epsilon 4$. Results from the Rotterdam Study show that smokers who were not carriers of the $A P O E-\epsilon 4$ allele had a fourfold increased $\mathrm{RR}$ of $\mathrm{AD}(\mathrm{RR}=4.6 ; 95 \%$ CI, 1.5 to 14.2 ).

Arguments have been posed to explain the relationship between smoking and $\mathrm{AD}$. These discussions have focused on previous case-control studies reporting a lower risk for $\mathrm{AD}$ associated with smoking. Several authors have argued that this protective association may have been related to differential survival based on genetic alterations. ${ }^{6,24-26} \mathrm{~A}$ similar argument could be made for our finding among those who quit smoking. There was a suggestion of a protective effect among those who quit smoking. This raises the question of whether those smokers who survived without encountering comorbid conditions (such as cardiovascular disease) commonly associated with tobacco use, who then quit smoking, may have acquired some additional protection, reducing their susceptibility to $\mathrm{AD}$. The capacity of cells to repair DNA declines with age, and is adversely altered with smoking. ${ }^{26-28}$ Therefore, those surviving former smokers may have more effective DNA repair mechanisms. As a consequence, the accumulation of aging-associated defects in DNA and DNA repair, which are presumed to be associated with $\mathrm{AD},{ }^{29}$ may be altered among surviving former smokers, reducing their susceptibility to $\mathrm{AD}$.

Our study demonstrates that $A P O E-\epsilon 4$ only slightly modifies the association between smoking and $\mathrm{AD}$ ( $\mathrm{RR}$ overall $=1.9$ verses $\mathrm{RR}$ without $\epsilon 4=$ 2.1). The link between smoking, $\mathrm{AD}$, and $A P O E$ genotype is controversial. From the Rotterdam Study, Van Duijn et al. ${ }^{10}$ and Ott et al. ${ }^{8}$ both demonstrated that $A P O E-\epsilon 4$ had a pronounced effect in patients with $\mathrm{AD}$. Their findings suggest that there is an increased risk of dementia and $\mathrm{AD}$ associated with smoking in those without the APOE- $\epsilon 4$ allele. However, due to the disproportional mortality rates between smokers and nonsmokers who are $A P O E-\epsilon 4$ carriers, the question remains whether there are additional factors in the causal chain possibly related to vascular disease. The results of our study failed to show any significant interaction between smoking, vascular disease, and $\mathrm{AD}$ or smoking, vascular disease, $\mathrm{AD}$, and $A P O E$. However, an acute effect of cigarette smoking is a reduction in cerebral perfusion. ${ }^{30}$ This poses a crucial threat to elders with existing cerebrovascular compromise. Smoking has also been linked to an increased risk of premature death. ${ }^{31}$

Ethnicity and educational attainment are recognized correlates of smoking, and both have been linked to $\mathrm{AD} .{ }^{31,32}$ After adjusting for these variables in the multivariate analysis, the smoking-associated risk of $\mathrm{AD}$ did not change. There was no proportional difference in tobacco use across ethnic groups. Both ethnicity and education may be considered proxies for various factors associated with socioeconomic status and health-related behavior. According to a recent review of smoking behavior across ethnicity and socioeconomic status, less educated African Americans were more likely to smoke compared with whites or Hispanics. ${ }^{32}$ Furthermore, African Americans were less likely to quit smoking than whites or Hispanics. ${ }^{32}$ Based on the findings of our comparative study, from a public health standpoint, equal emphasis should be placed on smoking cessation programs across ethnic groups and regardless of socioeconomic status among the elderly.

\section{References}

1. Whitehouse PJ, Martino AM, Wagster MV, et al. Reductions in $\left({ }^{3} \mathrm{H}\right)$ nicotinic acetylcholine binding in Alzheimer's disease and Parkinson's disease: an autoradiographic study. Neurology 1988;39:720-723.

2. Shimohama S, Taniguchi T, Fujiwara M, et al. Changes in nicotinic and muscarinic cholinergic receptors in Alzheimertype dementia. J Neurochem 1986;46:288-293.

3. Bird TD, Stranahan S, Sumi SM, Raskind M. Alzheimer's disease: choline acetyltransferase activity in brain tissue from clinical and pathological subgroups. Ann Neurol 1983;14:284293.

4. Perry EK, Gibson PH, Blessed G, et al. Neurotransmitter enzyme abnormalities in senile dementia. J Neurol Sci 1977;34: $247-265$

5. Rothman KJ. Modern epidemiology. Boston: Little, Brown, 1986.

6. Riggs JE. The protective influence of cigarette smoking on Alzheimer's and Parkinson's diseases: quagmire or opportunity for neuroepidemiology? Neurol Clin 1996;14:353-358. 
7. Riggs JE. Smoking and Alzheimer's disease: protective effect or differential survival bias? Lancet 1993;342:793-794.

8. Ott A, Slooter AJC, Hofman A, et al. Smoking and risk of dementia and Alzheimer's disease in a population-based cohort study: the Rotterdam Study. Lancet 1998;351:18401843.

9. Wilson PWF, Schaefer EJ, Larson MG, Ordovas JM. Apolipoprotein E alleles and risk of coronary disease: a metaanalysis. Arterioscler Thromb Vasc Biol 1996;16:1250-1255.

10. VanDuijn CM, Havekes LM, Van Broeckhoven C, et al. Apolipoprotein $\mathrm{E}$ genotype and association between smoking and early onset Alzheimer's disease. BMJ 1995;310:627-631.

11. Hardy J, Roberts GW. Smoking and neurodegenerative disease. Lancet 1993;342:1238. Letter.

12. Stern Y, Andrews H, Pittman J, et al. Diagnosis of dementia in a heterogenous population: development of a neuropsychological paradigm and quantified correction for education. Arch Neurol 1992;49:453-460.

13. Pittman J, Andrews H, Tatemichi T, et al. Diagnosis of dementia in a heterogenous population: a comparison of paradigm-based diagnosis and physician's diagnosis. Arch Neurol 1992;49:461-467.

14. American Psychiatric Association. Diagnostic and statistical manual of mental disorders. 4th ed. Washington, DC: American Psychiatric Association, 1994.

15. McKhann G, Drachman D, Folstein M, et al. Clinical diagnosis of Alzheimer's disease: report of NINCDS-ADRDA Work Group under the auspices of the Department of Health and Human Services Task Force on Alzheimer's Disease. Neurology 1984;34:939-944.

16. Hughes CP, Berg L, Daniziger WL, Cohen LA, Martin RL. A new clinical scale for the staging of dementia. Br J Psychol 1982;140:566-572.

17. The Bureau of the Census of Population and Housing. 1990: Summary tape file 1. Washington, DC: The Bureau of Census, 1991.

18. Mayeux R, Ottman R, Tang M-X, et al. Genetic susceptibility and head injury as risk factors for Alzheimer's disease among community-dwelling elderly persons and the first degree relatives. Ann Neurol 1993;33:494-501.
19. Hixson JE. Apolipoprotein E polymorphisms affect atherosclerosis in young males. Pathobiological Determinants of Atherosclerosis in Youth (PDAY) Research Group. Arterioscler Thromb 1991;11:1237-1244.

20. Hixson J, Vernier D. Restriction isotyping of human apolipoprotein $\mathrm{E}$ by gene amplification and cleavage with $\mathrm{HhaI}$. J Lipid Res 1991;31:545-548.

21. Maestre G, Ottman R, Stern Y, et al. Apolipoprotein E and Alzheimer's disease: ethnic variation in genotypic risks. Ann Neurol 1995;37:254-259.

22. Fleiss JL. Statistical methods for rates and proportions. New York: John Wiley and Sons, 1981.

23. Korn EL, Graubard BI, Midthune D. Time-to-event analysis of longitudinal follow-up of a survey: choice of the time scale. Am J Epidemiol 1997;145:72-80.

24. Larrick JW, Wright SC. Smoking and neurodegenerative diseases. Lancet 1993;342:1238.

25. Plassman BL, Helms M, Welsh K, et al. Smoking, Alzheimer's disease, and confounding with genes. Lancet 1995;345:387.

26. Pincheira J, Gallo C, Bravo M, Navarrete MH, Lopez-Saez JF. $\mathrm{G}_{2}$ repair and aging: influence of donor age on chromosomal aberrations in human lymphocytes. Mutat Res 1993; 295:55-62.

27. Au WW, Walker DM, Ward JB, et al. Factors contributing to chromosome damage in lymphocytes of cigarette smokers. Mutat Res 1991;260:137-144.

28. Cruickshank JM, Neil-Dwyer G, Dorrance DE, Hayes Y, Patel S. Acute effects of smoking on blood pressure and cerebral blood flow. J Hum Hypertens 1989;3:443-449.

29. Boerrigter METI, Wej JY, Vijg J. DNA repair and Alzheimer's disease. J Gerontol 1992;47:177-184.

30. Doll R, Peto R, Wheatly K, Gray R, Sutherland I. Mortality in relation to smoking: 40 years' observations on male British doctors. BMJ 1994;309:901-911.

31. Lockery SA, Stanford EP. Physical activity and smoking: gender comparisons among older African-American adults. J Health Care Poor Underserved 1996;7:232-251.

32. Siegel D, Faigeles B. Smoking and socioeconomic status in a population-based inner city sample of African-Americans, Latinos, and whites. J Cardiovasc Risk 1996;3:295-300. 


\title{
Neurology
}

\author{
The influence of smoking on the risk of Alzheimer's disease \\ C. Merchant, M.-X. Tang, S. Albert, et al. \\ Neurology 1999;52;1408 \\ DOI 10.1212/WNL.52.7.1408
}

\section{This information is current as of April 1, 1999}

\section{Updated Information \& Services}

\section{References}

Citations

Permissions \& Licensing

Reprints including high resolution figures, can be found at: http://www.neurology.org/content/52/7/1408.full.html

This article cites 27 articles, 7 of which you can access for free at: http://www.neurology.org/content/52/7/1408.full.html\#\#ref-list-1

This article has been cited by 23 HighWire-hosted articles: http://www.neurology.org/content/52/7/1408.full.html\#\#otherarticles

Information about reproducing this article in parts (figures,tables) or in its entirety can be found online at:

http://www.neurology.org/misc/about.xhtml\#permissions

Information about ordering reprints can be found online:

http://www.neurology.org/misc/addir.xhtml\#reprintsus

Neurology $®$ is the official journal of the American Academy of Neurology. Published continuously since 1951, it is now a weekly with 48 issues per year. Copyright . All rights reserved. Print ISSN: 0028-3878.

Online ISSN: 1526-632X.

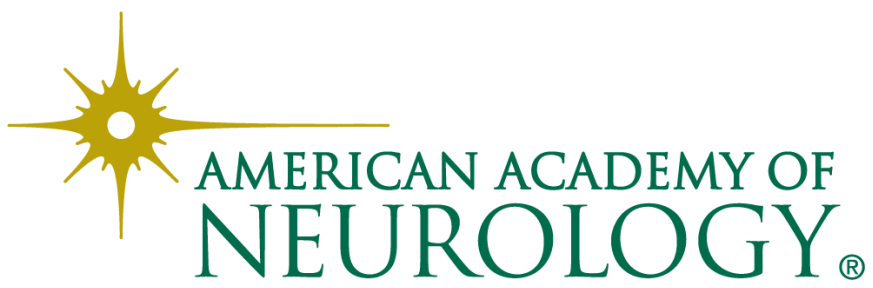

